\title{
Controls on facies mosaics of carbonate platforms: a case study from the Oxfordian of the Swiss Jura
}

\author{
ANDRÉ STRASSER and STÉPHANIE VÉDRINE \\ Department of Geosciences, University of Fribourg, CH-1700 Fribourg, Switzerland \\ (E-mail: andreas.strasser@unifr.ch)
}

\begin{abstract}
Modern shallow-water carbonate systems commonly display a complex pattern of juxtaposed depositional environments with a patchy facies distribution (facies mosaics). On ancient carbonate platforms, the reconstruction of lateral facies distribution is often hampered not only by discontinuous outcrop but also by lack of sufficiently high time resolution. This case study from the Oxfordian (Late Jurassic) of the Swiss Jura Mountains demonstrates a way to improve the temporal and spatial resolution for the interpretation of carbonate rocks. Sequence-stratigraphic and cyclostratigraphic analyses have been performed that provide a basis for defining depositional sequences, which formed through sea-level changes that were induced by the 400-, 100- and 20-kyr orbital cycles. On the 100-kyr scale, sequence boundaries are well developed and can be correlated between sections. However, identification and correlation of sequences related to the 20-kyr cycle may be difficult if local processes overprinted the record of orbitally controlled sea-level changes. The reconstruction of facies distribution along selected time lines gives a dynamic picture of platform evolution with time steps of a few ten thousand years and helps to interpret the controlling factors such as differential subsidence, low-amplitude eustatic sea-level fluctuations, climate and ecology of the carbonate-producing organisms. Reefs and ooid shoals developed preferentially on topographic highs and thus accentuated platform morphology. Siliciclastics were shed onto the platform during sea-level falls and increased rainfall in the hinterland; their distribution was controlled by platform morphology. Siliciclastics and associated nutrients hindered carbonate production and thus indirectly influenced platform morphology. In addition to these controls, random processes acted on the smaller-scale facies relationships. Sedimentation rates can be estimated for each facies type over time spans of 10-20 kyr. They can thus be compared more easily with Holocene rates than if averaged over millions of years. This study shows that the Oxfordian platform in the Swiss Jura was as complex and dynamic as Holocene carbonate systems.
\end{abstract}

Keywords Carbonate system, facies, sea-level changes, cyclostratigraphy, Oxfordian, Switzerland.

\section{INTRODUCTION}

When flying over modern carbonate platforms, when walking on tidal flats, emergent ooid shoals or coral cays, and when snorkelling in shallow lagoons and over the reef edge it is evident that there is a large array of juxtaposed sedimentary and ecological environments. None of these environments is stable: carbonate mudbanks and sand shoals shift laterally due to tidal and long-shore currents and by doing so modify also the environments adjacent to them. A good example is the spit in Fig. 1a that is about to isolate a lagoon from the open ocean, thus creating a drastic contrast in energy and salinity levels. Storm waves and storm-induced currents lead to abrupt changes by redistributing sediment in large quantities, and by breaching or creating barriers between depositional environments (Fig. 1b). Storms also induce ecological changes by breaking corals, which are later replaced by other species. On longer timescales (tens, hundreds, or thousands of years), fluctuations in climate and relative sea level become important factors that lead to changes in 
(a)

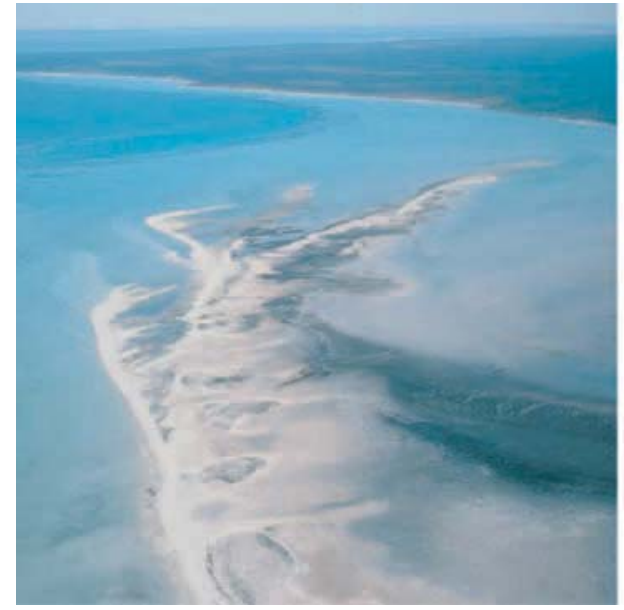

(b)

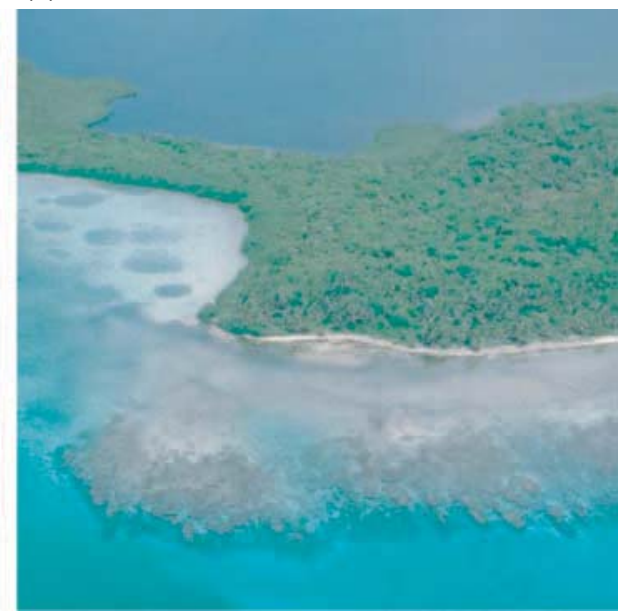

Fig. 1. Examples of modern carbonate depositional systems displaying various, juxtaposed environments. (a) Complex spit of carbonate sands migrating northward along the coast of Shark Bay, Western Australia. Note the closing of lagoon to the right, with microbial mats (black in picture) developing in the most protected areas. (b) Reef with spurs and grooves on the eastern (seaward) side of Turneffe Islands, Belize. It is separated from the protected central lagoon (top of picture) by only a thin vegetated land bridge.

composition and distribution of the depositional environments. Increased rainfall in the hinterland carries siliciclastics and nutrients into the carbonate system, whereas aridity increases salinity in shallow lagoons. Water temperature, water transparency, water geochemistry, nutrient availability and sediment input are all factors that control the ecology of carbonate-producing organisms. Sealevel rise leads to flooding of barriers and shallow islands and causes rapid environmental changes once the threshold is passed. Light-dependent ecosystems may lose the photic zone unless they are able to keep up with sea-level rise. Sea-level fall, on the other hand, brings light to deeper environments and can open new habitats for carbonate-producing organisms. In other positions on the platform, sea-level fall leads to subaerial exposure of previously subtidal habitats and shuts off carbonate production.

Considering the complexity of today's shallow-water carbonate systems (Fig. 2) it must be expected that the sedimentary record of such systems is also complex. There is no reason to believe that Phanerozoic carbonate systems were less complex than modern ones, although platetectonic configuration, climatic conditions, amplitude of sea-level changes, seawater geochemistry and the evolution of the participating organisms certainly preclude a direct comparison. Further complexity is added by the fact that only a part of the history is recorded: information is missing due to non-deposition and/or erosion, only part of

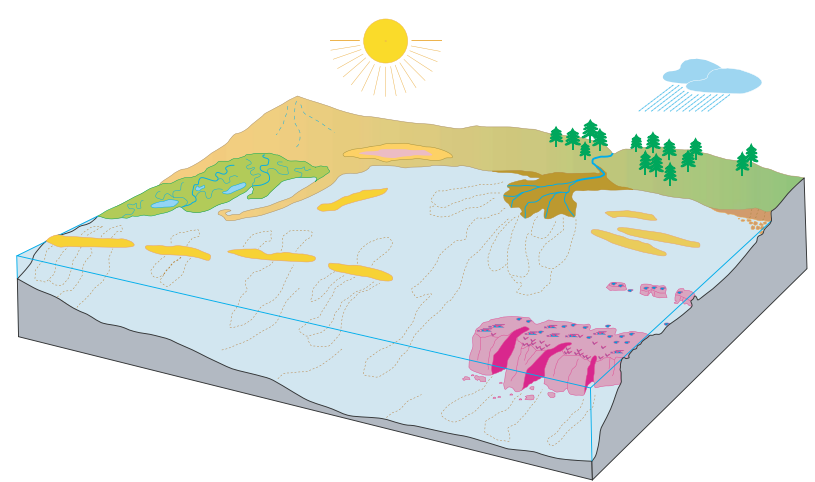

Fig. 2. Sketch illustrating that different depositional environments coexist in shallow carbonate-dominated systems (tidal flats, sabkhas, siliciclastic deltas, beaches, carbonate sand shoals, lagoons, coral reefs). Arid and humid endmembers exist but also intermediate cases occur, with seasonal alternations between more humid and more arid phases. Modified from Strasser et al. (1999).

the organisms participating in the ecosystems are fossilized, and diagenesis may create a preservational bias.

The carbonate facies models of Wilson (1975), Jones \& Desrochers (1992) and Flügel (2004) describe facies zones that give a general picture of the potential distribution of sedimentary environments and biota. Read (1985), Burchette \& Wright (1992), and Pomar (2001) have emphasized the differences between the geometries of carbonate ramps and platforms and discussed their relation to facies distribution and productivity of carbonate-secreting organisms. Carbonate 
factories in different palaeoceanographic, palaeoclimatological and palaeoecological settings have been discussed by Schlager (2003) and Mutti \& Hallock (2003). Wright \& Burgess (2005) acknowledge the high temporal and spatial variability of depositional environments that leads to facies mosaics, which correspond better to reality than the linear arrangement of facies belts as shown in many models. For the Holocene, many examples of facies mosaics have been published: Gischler \& Lomando (1999) documented the high complexity of facies distribution of isolated carbonate platforms in Belize; Riegl \& Piller (1999) mapped the great lateral variability of coral carpets, reefs, and carbonate sand in Safaga Bay (Egypt); and Rankey (2002) discussed the fractal nature of facies patches on the tidal flats of Andros Island (Bahamas). However, despite the ever more detailed studies of recent and ancient carbonate facies and the undeniable progress in the understanding of shallow-water carbonate systems, there is still a discrepancy in the space and time resolution between the interpretations of ancient and modern depositional environments. This is a result of the difficulty in obtaining continuous, three-dimensional information on facies and sedimentary structures in ancient carbonates, and from the difficulty of defining a precise time-frame that allows reconstructing isochronous depositional surfaces in the rock record.

In this paper a case study is presented where the evolution of carbonate facies through space and time is monitored with a time resolution of 10-20 kyr. This allows for a realistic evaluation of the controlling parameters such as sea-level and climate changes.

\section{STUDIED SECTIONS, PALAEOGEOGRAPHY AND STRATIGRAPHY}

The Oxfordian mixed carbonate-siliciclastic sedimentary succession in the Swiss Jura Mountains has been studied extensively over the past few decades (Ziegler, 1956; Bolliger \& Burri, 1970; Gygi, 1986, 1995; Gygi \& Persoz, 1986; Pittet, 1996; Dupraz, 1999; Hug, 2003; Védrine, 2007). For the present work, five sections were selected (Fig. 3) focusing on the uppermost part of the Günsberg and Röschenz members and the lower part of the Hauptmumienbank and Steinebach members (Fig. 4). The sections were logged along road cuts in the cases of Pertuis, Savagnières, Gorges de Court

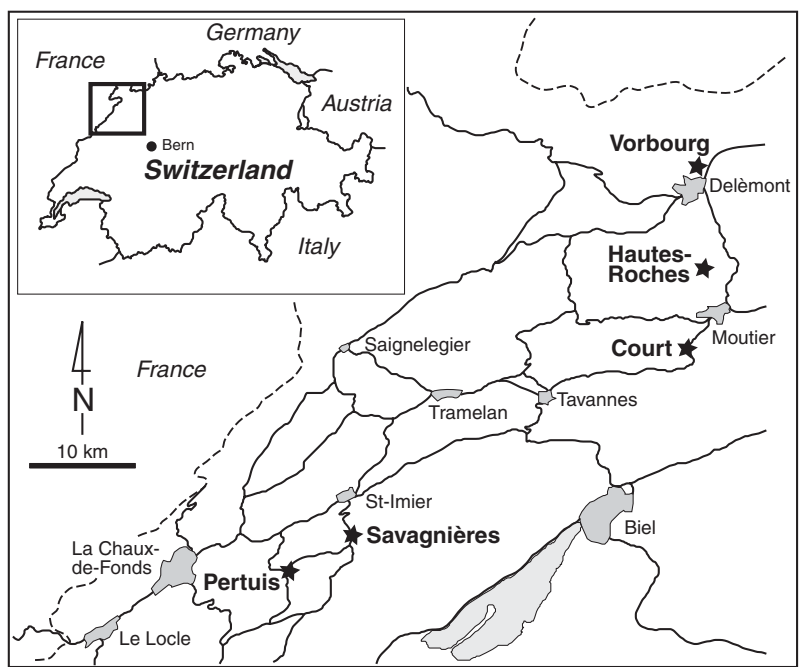

Fig. 3. Location of the five studied sections in the Swiss Jura Mountains. Solid lines are roads, dashed line is the Swiss-French border.

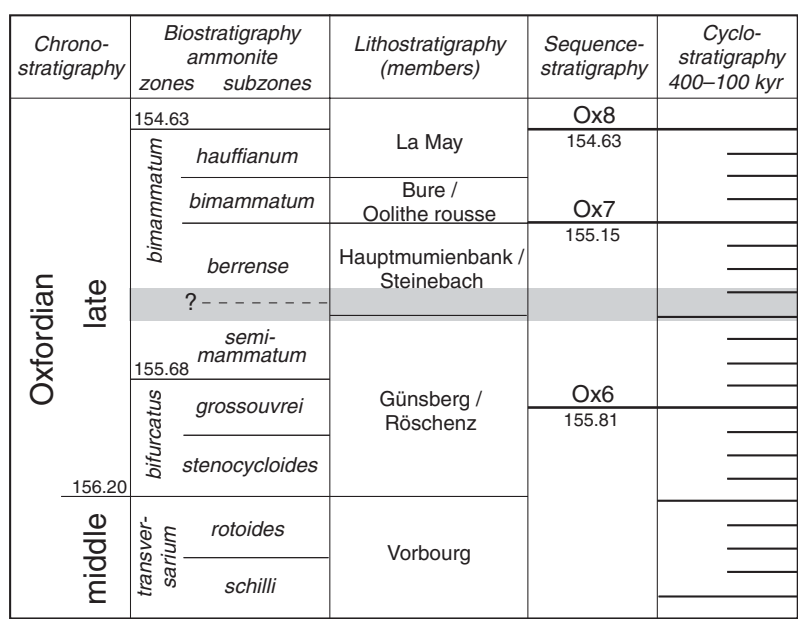

Fig. 4. Stratigraphic framework of the sections studied. A high-resolution analysis is presented for the interval marked in grey (Fig. 9). Chrono-, bio- and sequence stratigraphy based on Hardenbol et al. (1998), lithostratigraphy according to Gygi (1995), cyclostratigraphy according to Pittet (1996), Pittet \& Strasser (1998) and Hug (2003).

and Vorbourg, and along an abandoned forestry path in the case of Hautes-Roches. Unfortunately, outcrop conditions did not allow the strata to be followed laterally over more than a few metres, and the sections are widely spaced. The facies analysis is based on continuous outcrop observation with a hand lens and on 433 thin-sections and marl washings (Védrine, 2007). Particular attention was paid to bedding surfaces in order to distinguish between hardgrounds, firmgrounds and erosion surfaces. 


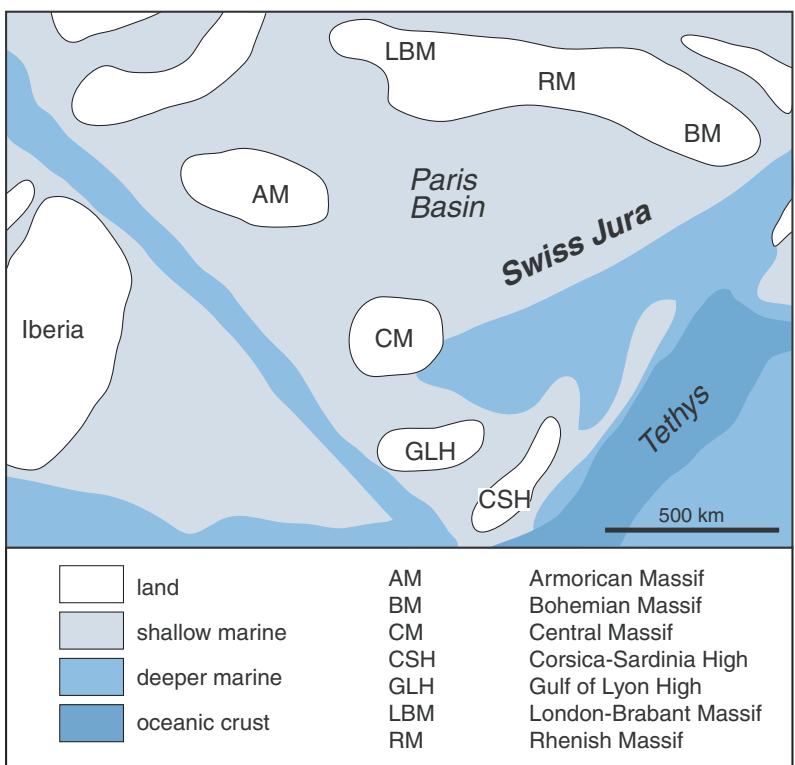

Fig. 5. Late Jurassic palaeogeography of the northern margin of the Tethys Ocean, the Swiss Jura and the Paris Basin (modified from Ziegler, 1988).

The upper part of the Günsberg Member and its lateral equivalent, the Röschenz Member, is dominated by marls and isolated limestone beds with shallow-lagoonal flora and fauna. Freshwater algae, root traces and plant debris occur locally. The Hauptmumienbank Member is composed of massive limestone beds rich in oncoids. It is laterally replaced by the Steinebach Member, which is characterized by oolites and coral patch reefs. These sediments were deposited on the shallow platform between the Paris Basin to the north and the Tethys Ocean to the south, in the position of today's Swiss Jura (Fig. 5). Siliciclastics were shed from the Bohemian and the Central massifs. Palaeolatitude was about $26-27^{\circ} \mathrm{N}$ (Dercourt et al., 1993).

The interval studied has been dated by mineralstratigraphic correlations with ammonite-bearing horizons (Gygi \& Persoz, 1986; Gygi, 1995): it lies in the lower part of the bimammatum zone (semimammatum and berrense subzones) of the late Oxfordian (Fig. 4). Gygi et al. (1998) and Hug (2003) have established the sequence-stratigraphic framework, which implies that the interval studied is situated between sequence boundaries Ox6 and Ox7 of Hardenbol et al. (1998). The sequence-stratigraphic terminology follows Vail et al. (1991).

Pittet (1996), Pittet \& Strasser (1998), Strasser et al. (2000) and Hug (2003) have performed a cyclostratigraphic analysis of the middle and late Oxfordian of the Swiss Jura, applying the methodology presented in Strasser et al. (1999). Detailed analyses of thin-sections and sedimentary structures allow identification of deepening and shallowing trends of facies evolution. Accordingly, elementary, small-scale and medium-scale depositional sequences have been defined in each section studied, which then were correlated over the entire study area. It is seen that four smallscale sequences regularly build up a mediumscale sequence, and that there are two to six (in many cases five) elementary sequences comprised in a small-scale sequence. The bifurcatus and bimammatum zones contain 16 small-scale sequences (Fig. 4). According to Hardenbol et al. (1998), based on the absolute dating by Gradstein et al. (1995), this interval lasted about $1.6 \mathrm{Myr}$. This implies that one small-scale sequence lasted $100 \mathrm{kyr}$, which corresponds to the duration of the short eccentricity cycle of the Earth's orbit (Berger et al., 1989). A medium-scale sequence would then represent the long eccentricity cycle of $400 \mathrm{kyr}$, and an elementary sequence (where it can be identified) the precession cycle of $20 \mathrm{kyr}$. From the observed facies trends it appears that sea level was a major controlling factor in sequence formation. It is therefore suggested that orbital cycles translated into climate changes (Milankovitch cycles), which in turn controlled sea-level fluctuations. Between sequence boundaries Ox6 and Ox7 lie eight small-scale sequences but only $660 \mathrm{kyr}$ are allocated for this interval by Hardenbol et al. (1998). On the other hand, four small-scale sequences are contained between Ox7 and Ox8, an interval which Hardenbol et al. (1998) estimate to have lasted $520 \mathrm{kyr}$ (Fig. 4). These discrepancies are due to the error margins in absolute dating of stage boundaries (Gradstein et al., 1995) from which Hardenbol et al. (1998) have interpolated their age estimations, and/or to the possibility that a sequence boundary dated in the basin by Hardenbol et al. (1998) may have its strongest expression on the platform not necessarily at the same time (Strasser et al., 2000). Also, some orbitally induced sea-level changes may not have been recorded in the sedimentary system (see below).

\section{DEFINITION AND CORRELATION OF DEPOSITIONAL SEQUENCES}

\section{Small- and medium-scale sequences}

Within the general sequence-stratigraphic and cyclostratigraphic framework discussed above, the 
sections studied are first correlated on the level of small-scale (100-kyr) and medium-scale (400-kyr) sequences (Fig. 6). Sequence boundaries are placed where facies indicate relatively shallow water or intertidal conditions with birdseyes and microbial mats, where very thin elementary sequences suggest that accommodation was low, and/or where channels and overlying lithoclasts imply erosion. Maximum-flooding surfaces or intervals are indicated by relatively deep facies, by shifts from carbonate-dominated deposits to marls that imply highstand progradation, and/or by strong bioturbation due to low sedimentation rates. In one section alone it is often difficult to place these boundaries unequivocally and to estimate their magnitude (i.e. if they belong to elementary, small-scale, or medium-scale sequences). Through correlation with other sections, however, a best-fit solution can be found (Fig. 6).

The model in Fig. 7 illustrates how superimposed high-frequency sea-level changes lead to the formation of complexly stacked depositional sequences in one spot on the shallow platform. Adding to this platform morphology and the fact that different depositional environments react differently to the same sea-level change, it is to be expected that sequence definition and correlation is often not straightforward. For example, a reef may create a shallowing-up succession if it catches up with rising sea level (Kendall \& Schlager, 1981), whereas during the same time a lagoon will produce a deepening-up succession. Also, if sealevel fall is minor, it will lead to emersion and a well-developed sequence boundary in previously very shallow environments, whereas in a deeper lagoon the same sea-level fall will not be recorded at all, or only indirectly through input of material reworked from the emergent areas ('hidden SB' in Fig. 7).

Overlying the coral reefs, ooid shoals and oncoid lagoons shown in the lowermost parts of the sections in Fig. 6, there is rapid change towards low-energy, plant-bearing strata (at $4 \mathrm{~m}$ in Gorges de Court and at $6.3 \mathrm{~m}$ in Hautes-Roches) and local erosion surfaces (at $5 \mathrm{~m}$ in Pertuis and at $6.3 \mathrm{~m}$ in Hautes-Roches). This is interpreted as representing a sequence boundary on the 400-kyr scale. In Savagnières, this boundary has been placed according to the stacking pattern of the elementary sequences at $4.8 \mathrm{~m}$ : a thick elementary sequence following several thin ones implies a rapid increase in accommodation, which is attributed to transgression after the sequence boundary. The maximum flooding of the first medium-scale sequence coincides with the maximum-flooding surface of small-scale sequence 3 , which is developed as a strongly bioturbated surface in Pertuis, Savagnières and Court, and as a hardground at Hautes-Roches (Figs 6 and 8). According to the biostratigraphic position, the following medium-scale sequence boundary corresponds to Ox6 of Hardenbol et al. (1998). It displays plant fragments at Pertuis and tidal-flat facies at Gorges de Court but is not very conspicuous in Savagnières or Hautes-Roches.

The overlying medium-scale sequence begins with locally well-developed ooid shoals in smallscale sequence 5. Maximum-flooding conditions are implied by a rapid change to a marl-dominated succession in Pertuis and Hautes-Roches, and by a change from high-energy shoals to lowenergy lagoonal deposits in Savagnières. However, there is no feature in Gorges de Court that would allow placing this maximum flooding. The following medium-scale sequence boundary marks the end of the marly facies and the beginning of the massive beds of the Hauptmumienbank and Steinebach members. Small-scale sequence 9 generally is very thick and thus suggests rapid gain in accommodation. This sequence will be the subject of a high-resolution analysis in the next chapter. Maximum flooding of the corresponding medium-scale sequence is inferred by the appearance of open-marine fauna in all sections and by a change from ooid dunes and coral reefs to marly and low-energy facies in Court, Hautes-Roches and Vorbourg (Fig. 6).

When comparing the facies of time-equivalent small-scale sequences between the sections it becomes evident that there are significant lateral facies changes: for example, ooid shoals are laterally replaced by oncoid lagoons, or tidal flats are juxtaposed to marls and palaeosols (Figs 6 and 8). Ooid shoals do not always occur at the same time in the sections studied, which suggests that they migrated across the platform through time or were stranded in one position and later reinitiated in another one. Futhermore, the distribution of siliciclastics is heterogeneous, which may be due to preferential deposition in troughs. This and the varying thicknesses of the sequences point to a highly structured platform.

\section{Elementary sequences}

An elementary sequence is the smallest recognizable unit of the sedimentary record and is defined as having formed through one cycle of environmental change (Strasser et al., 1999). However, if this cycle is not strong enough to create a 


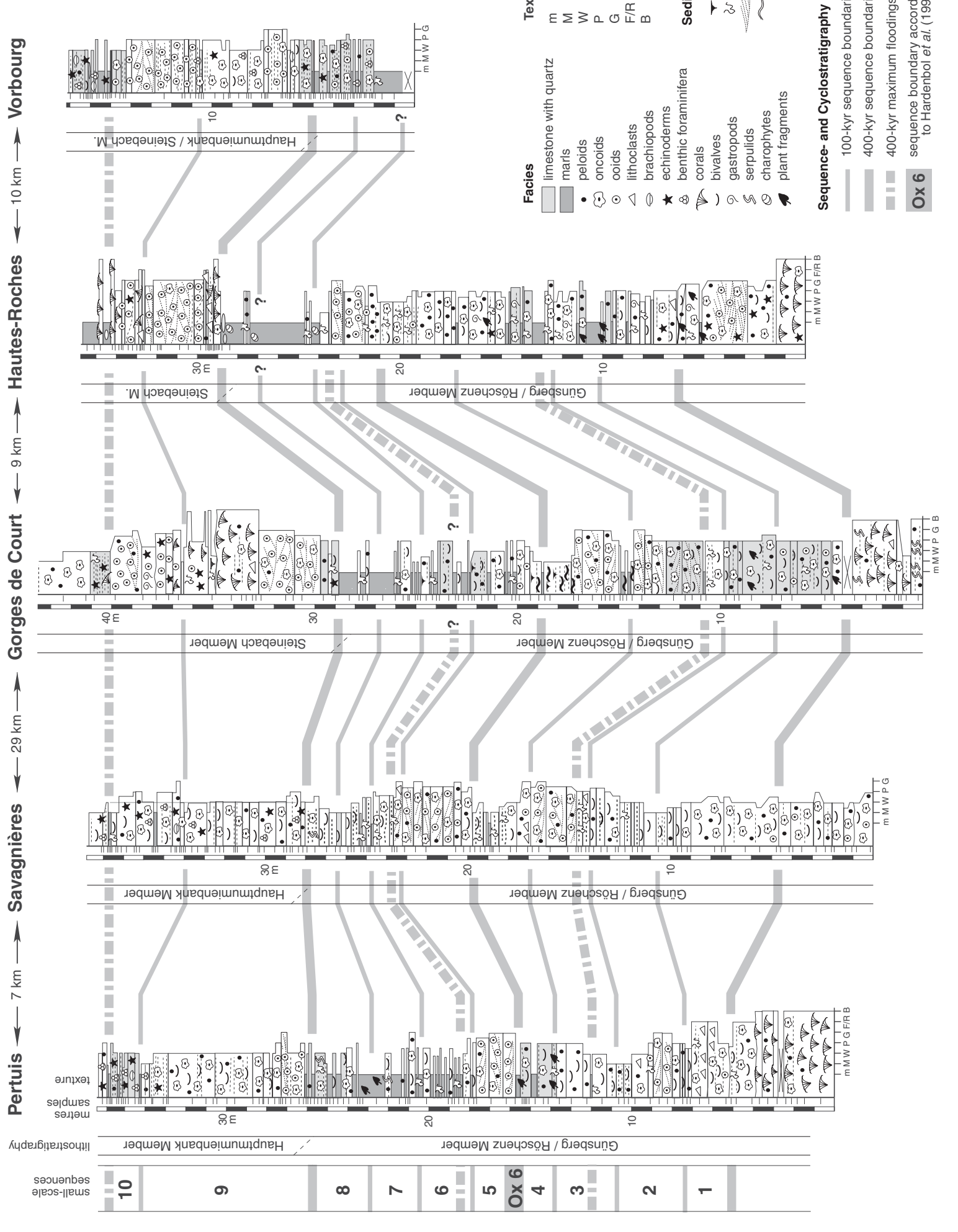

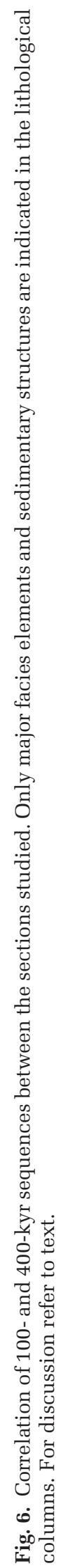




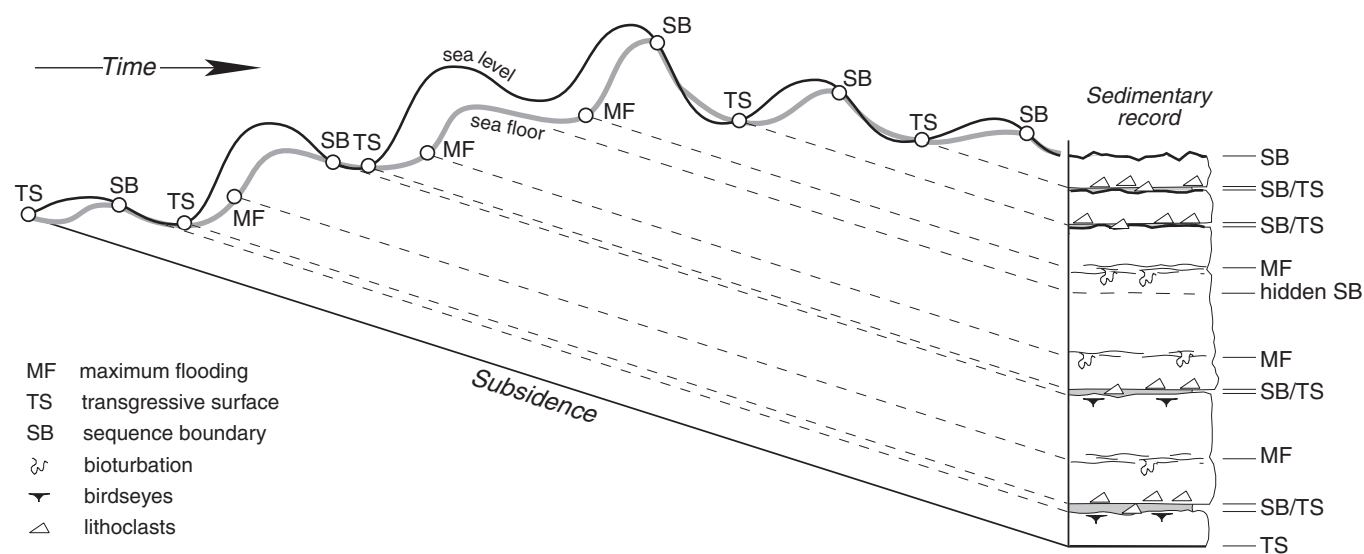

Fig. 7. Superimposed frequencies of sea-level fluctuations lead to a complex sedimentary record. Note that sequence boundaries may be hidden if sea-level fall is not sufficient to create a facies contrast. When accommodation is low due to a long-term sea-level fall, elementary sequences become very thin and have eroded tops, or they are not deposited at all. For more discussion refer to text. Modified from Strasser et al. (2004).

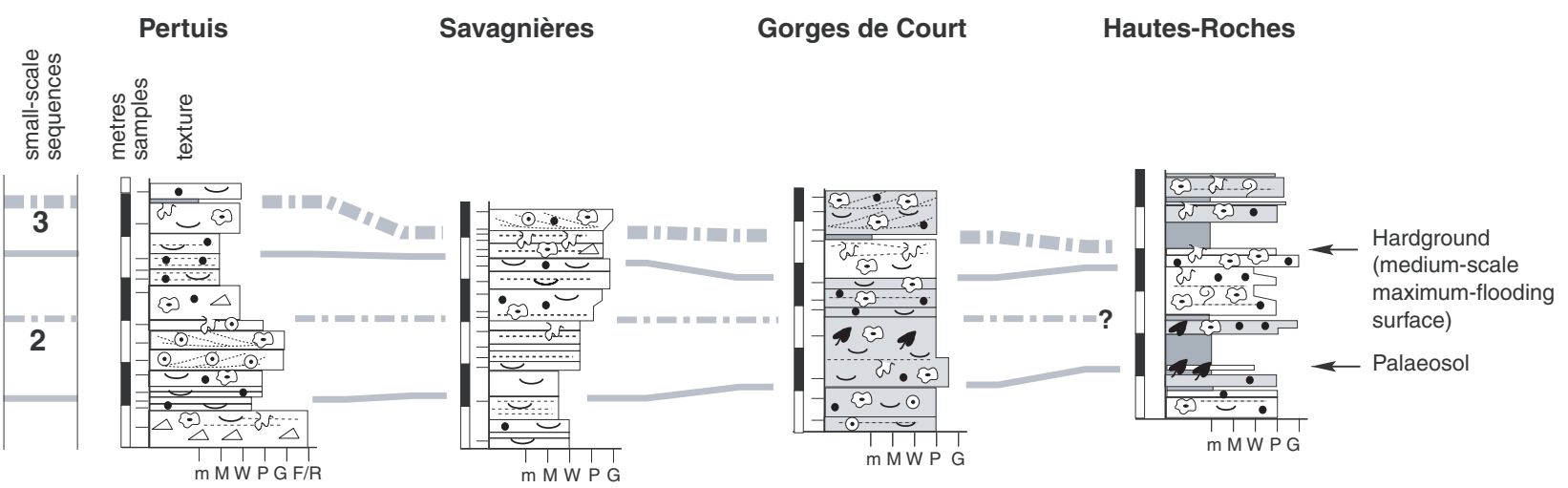

Fig. 8. Correlation of small-scale sequence 2 (compare with Fig. 6). While at Pertuis there is a well developed maximumflooding surface separating the transgressive ooid shoals from the muddy lagoonal highstand, the transgressive deposits overlying a palaeosol at Hautes-Roches are rich in siliciclastics and the maximum flooding of the small-scale sequence is difficult to place. The maximum flooding of the medium-scale sequence, however, is expressed by a hardground within small-scale sequence 3. Symbols are as in Fig. 6.

facies contrast, it will not be expressed in the record. When accommodation is low, elementary sequences may not be deposited or eroded ('missed beats' of Goldhammer et al., 1990). Consequently, the best chance of recording elementary sequences is during long-term transgression when accommodation space is created while carbonate production keeps up and the depositional environments stay shallow. For a detailed analysis we have therefore chosen small-scale sequence 9 (Figs 6 and 9), which formed at the beginning of a medium-scale (400-kyr) transgression (Hug, 2003).

Figure 9 presents a correlation between the five sections studied. Small-scale sequence 9 is composed of individual beds, which are separated by thin layers of marls. The number of beds varies from one section to the other. The identification of elementary sequences is most straightforward at Vorbourg, where small channels indicate shallowest water and thus sequence boundaries. The maximum-flooding surface of small-scale sequence 9 is implied by the change from high-energy to lowenergy facies and by bioturbation. In the second and third elementary sequence, their maximum flooding can be identified by thin marly layers and subtle facies changes. The Hautes-Roches section displays coral carpets at the base. The top of a conspicuous ooid sand wave is interpreted as the maximum-flooding surface of small-scale sequence 9. In the following ooid dunes it is 


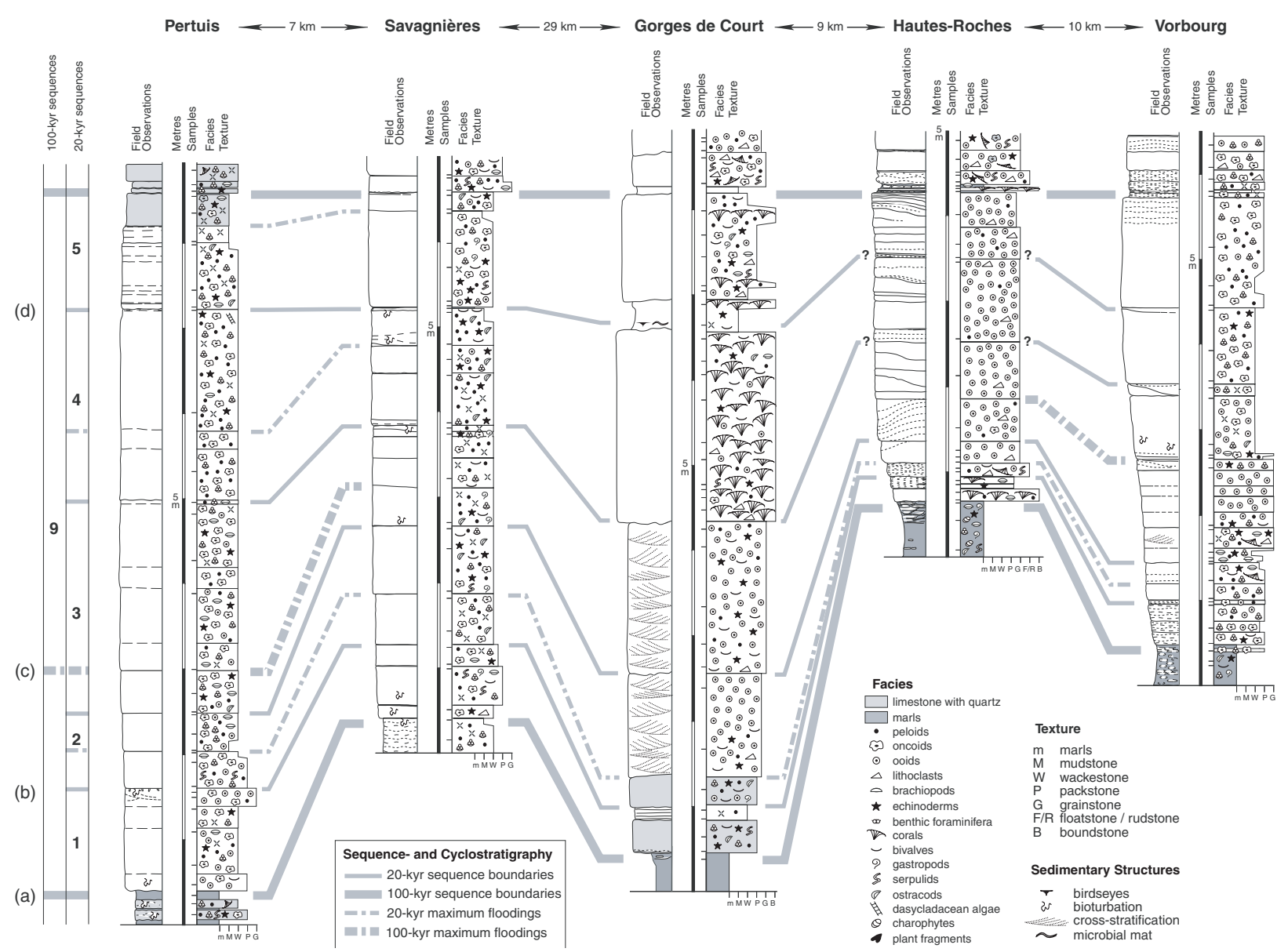

Fig. 9. Correlation of elementary (20-kyr) sequences that compose small-scale sequence 9 (Fig. 6). Only major facies elements and sedimentary structures are indicated in the lithological columns. a, b, c and d indicate time lines along which the reconstructions in Fig. 10 have been made. For discussion see text.

not possible to distinguish between reactivation surfaces and elementary sequence boundaries, and the correlation is speculative. In the Gorges de Court section, a thin interval with birdseyes and microbial mats covers a coral reef. This is attributed to the top of elementary sequence 4 . The sections of Pertuis and Savagnières display only slight facies contrasts. The correlation of the elementary sequence boundaries is therefore guided by the most conspicuous bedding surfaces. However, maximum-flooding surfaces may also be expressed as bedding surfaces. This is explained by the ponding of clays during fastest relative sealevel rise, while the clays at sequences boundaries are washed onto the platform as a result of rapid sea-level fall (Strasser \& Hillgärtner, 1998). As for the small-scale sequences (Fig. 6), the correlation at the level of the elementary sequences represents a best-fit solution.

\section{CONTROLS ON FACIES DISTRIBUTION}

The complex interplay of many factors controls carbonate-producing ecosystems, sediment distribution and the final sedimentary record; however, the most important parameters will be discussed separately.

\section{Sea-level change}

Facies evolution in many small-scale sequences clearly indicates that water depth, water energy and/or marine influence have increased then decreased during the deposition of one sequence (Figs 6 and 8). In other small-scale sequences, facies show a rather aggradational pattern, then a rapid shallowing at the sequence boundary. The fact that the boundaries and in some cases also the maximum-flooding surfaces of these sequences 
can be followed over tens of kilometres and that they are independent of facies is best explained by sea-level changes that affected the entire platform. Depending on the position on the platform and on the type of environment (Fig. 2), a sea-level cycle produced a deepening and shallowing or an aggradational pattern. Thicknesses of the small-scale sequences vary between 2 and $8 \mathrm{~m}$ (Fig. 6). If facies-dependent decompaction is applied (procedure described in Strasser et al., 2004) this would correspond to about 3 to $15 \mathrm{~m}$. The amplitude of a sea-level change that created a specific sequence must have been at least as high as this decompacted sequence if it ends in tidal facies, or somewhat higher if the sequence stayed subtidal throughout.

In many elementary sequences it is difficult to discern deepening and shallowing facies evolutions. However, bed limits may display features (e.g. hardgrounds, bioturbation, channelling) that indicate changes in the depositional environment (Fig. 9). Bed limits are caused by thin marly layers. The input of clays can be related to sea-level changes (erosion of soils during sea-level lowstands, ponding in deeper environments during maximum flooding), to more rainfall in the hinterland increasing fluvial transport, and/or to currents that redistribute the clays independently of sea level or climate (Strasser \& Hillgärtner, 1998). In ooid shoals, bedding limits form through bedform migration and channelling. These limits are first of all controlled by tidal currents, and only the intensity of the latter may be related to sea level. Consequently, a bed of ooid grainstone seen in outcrop does not necessarily represent a cycle of sea-level change.

The hierarchical stacking of elementary, smallscale and medium-scale sequences and the biochronostratigraphic time control suggest that the formation of these sequences was in tune with the orbital cycles of precession, short eccentricity and long eccentricity, respectively (see above). The quasi-periodic perturbations of the Earth's orbit produce changes in the insolation received at the top of the atmosphere, which then translate into climate changes (Schwarzacher, 1993; De Boer \& Smith, 1994; Matthews \& Perlmutter, 1994). In the Late Jurassic, ice in high latitudes probably was present, but land-bound ice-volumes were too small to induce important glacio-eustatic fluctuations (Frakes et al., 1992; Eyles, 1993; Valdes et al., 1995). However, volume changes of alpine glaciers could have made a small contribution
(Fairbridge, 1976; Valdes et al., 1995). An important component in low-amplitude sea-level changes is thermal expansion and contraction of the uppermost layer of ocean water (Gornitz et al., 1982; Church \& Gregory, 2001). Contributions may also have been made by thermally induced volume changes in deep-water circulation (Schulz \& Schäfer-Neth, 1998), and/or by water retention and release in lakes and aquifers (Jacobs \& Sahagian, 1993). Consequently, it is assumed that Oxfordian high-frequency sea-level changes were coupled to climate changes, which themselves were linked to the Earth's orbital parameters. The above-mentioned mechanisms could easily produce the few metres of amplitude necessary for the accommodation of the observed depositional sequences.

On a shallow platform, even very low-amplitude sea-level changes can have dramatic effects. For example, a sea-level fall of a few tens of centimetres can lead to emersion and erosion of a reef that has previously built up to sea level, and ooid shoals can be forced to migrate laterally or will emerge to form islands. On the other hand, a small sea-level rise can flood a barrier that has hitherto protected a lagoon and produce a rapid change in water energy, salinity and ecology. Facies changes and depositional sequences can also be induced independently of sea level changes by lateral migration of sediment bodies controlled by currents (Pratt \& James, 1986) or by progradation (Ginsburg, 1971). Such 'autocyclic' processes may lead to stacked sequences but will never be able to create a hierarchical stacking pattern as observed in the sections studied (Strasser, 1991). In the definition of individual elementary sequences, however, such processes must be considered.

\section{Differential subsidence}

The Swiss Jura in Late Jurassic times was part of the passive northern margin of the Tethys Ocean (Fig. 5). The tectonic regime was extensional, and a pattern of structural highs and depressions formed (Allenbach, 2001). Average subsidence rates are estimated at $20-40 \mathrm{~m}$ per million years (Wildi et al., 1989). The thickness variations of the sections studied (Fig. 6) can therefore be attributed to differential subsidence of individual tectonic blocks. The general facies distribution in the sections studied suggests that the blocks were slightly tilted: coral reefs and ooid shoals developed on the higher margins towards the 


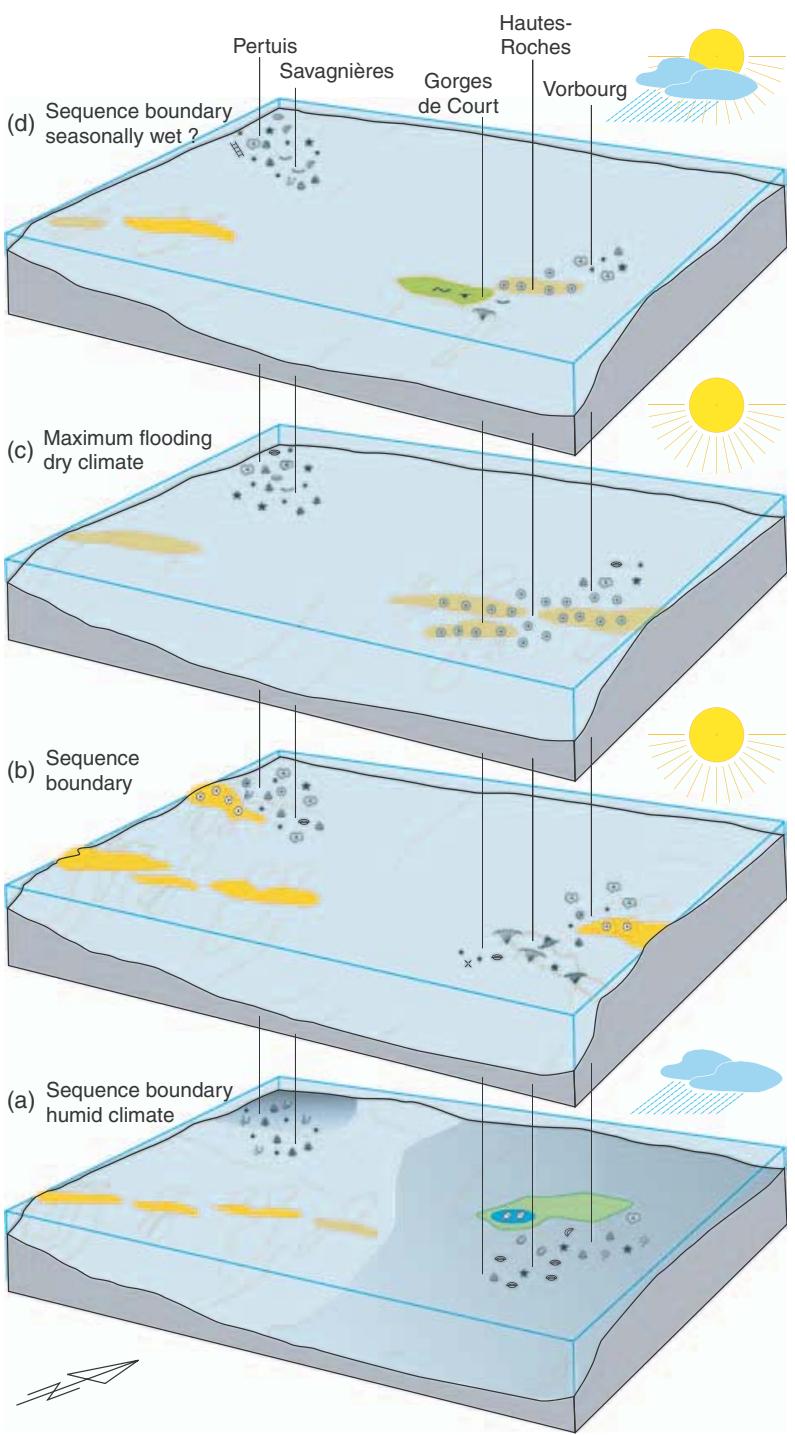

Fig. 10. Sketches of depositional environments along the time lines indicated in Fig. 9. Platform morphology has been reconstructed to be compatible with the evolution of facies and sequences observed in the sections studied. For discussion refer to text. No palinspastic correction has been applied: the distances between the sections may therefore be somewhat different from Late Jurassic times but their relative positions have not changed.

south, whereas lagoons formed in the depressions towards the north (Fig. 10). The relief created by tectonics therefore contributed significantly to the general facies distribution. Furthermore, the irregular distribution of siliciclastics (Fig. 6) can be explained by depressions, which were created by differential subsidence and served as conduits (Pittet, 1996; Hug, 2003). The preferential growth of reefs and the initiation of ooid shoals on tectonic highs further enhanced the relief.

\section{Climate}

General climate models for the Late Jurassic have been developed by Oschmann (1990), Frakes et al. (1992), Sellwood \& Valdez (1997), or Abbink et al. (2001). These models, however, do not consider short-term climate variations. Orbital cyclicity causes changes in the total amount of insolation and in its seasonal distribution, which then result in latitudinal shifting of atmospheric circulation cells and concomitant changes in seasonality, rainfall pattern, oceanic circulation and sea-surface temperatures (Matthews \& Perlmutter, 1994).

In the sections studied, siliciclastics are in many cases concentrated around small-scale sequence boundaries and associated with plant material (Fig. 6). This implies that during sea-level fall climate in the hinterland was rather humid, increasing the terrigenous runoff and allowing vegetation growth. Coral reefs and ooid shoals are situated preferentially in the trangressive parts of smallscale and medium-scale sequences in the absence of siliciclastics, suggesting a rather dry and warm climate. However, there are many exceptions to these trends, so that humid-dry changes can be considered as only one controlling factor among several others. There is no evidence for arid conditions as no evaporites have been observed in the sections studied. It is interesting to note that in Upper Oxfordian sections in Spain, in a more southern palaeolatitudinal position, the siliciclastics are preferentially associated with maximum flooding in small-scale sequences (Pittet \& Strasser, 1998). This implies that rainfall there occurred during rising sea-level and places the Spanish sections in a different palaeoclimatic zone than those in the Swiss Jura.

The estimation of water temperature is difficult. Based on $\delta^{18} \mathrm{O}$ analyses on modified whole rock, Plunkett (1997) derived an average palaeotemperature of $26-27^{\circ} \mathrm{C}$ for samples in the Vorbourg and Gorges de Court sections. The isotopic variations within individual depositional sequences, however, are too weak to be interpreted confidently as high-frequency temperature changes.

\section{Ecology}

The most conspicuous carbonate-producing ecosystems in the sections studied are coral patch reefs. They occur in different stratigraphic positions and the individual reef bodies never lived longer than the duration of an elementary sequence, i.e. $20 \mathrm{kyr}$ (Figs 6 and 9). The Oxfordian reefs 
in the Swiss Jura have been studied extensively by Dupraz (1999) and Dupraz \& Strasser (2002). Coral diversity is low to moderate. The corals are commonly bioeroded and covered by microencrusters (cyanobacteria, foraminifera, bryozoans, serpulids, sponges) and by microbialites. Conditions varied from oligotrophic allowing for healthy coral growth to meso- and eutrophic when nutrient levels were high and microbialite growth was favoured. Nutrient input was coupled with terrigenous input, which in addition diminished water transparency. This situation occurred preferentially when sea level was low (see above). Consequently, the trophic and photic conditions that controlled coral growth were directly linked to climatic and sea-level changes.

Micro-encrusters and microbialites also occur in oncoids, which are important components in the sections studied (Fig. 6). Other carbonate producers include echinoderms, foraminifera, brachiopods, bivalves, gastropods, ostracods and serpulids. Dasycladacean algae are rarely found, possibly due to early diagenetic aragonite dissolution. Charophytes occur only in the uppermost part of the Günsberg/Röschenz Member at Hautes-Roches and point to local development of freshwater ponds. Oncoids and the heterotrophic fauna are found in pure carbonates as well as in the facies containing siliciclastics, while the coral reefs flourished in the absence of siliciclastics.

\section{Facies mosaics}

Reconstructing the facies distribution on an entire platform and its evolution through time based on only five sections is of course a highly speculative enterprise. Nevertheless, there are certain clues that are given through the time lines established by the cyclostratigraphical analysis, and by the logical interpretation of the facies occurring along these time lines. For example, a wackestone with oncoids and ooids implies a low-energy lagoon, which was protected from the open ocean by an ooid shoal from where the ooids were washed in. If the ooids are corroded and/or encrusted, a time lag between ooid formation and deposition in the lagoon has to be postulated. For the reconstruction presented in Fig. 10, four time lines have been chosen: three sequence boundaries and a maximum-flooding surface (Fig. 9). According to our cyclostratigraphic analysis, the intervals between these lines represent 20, 30 and again $30 \mathrm{kyr}$, assuming in a simplified manner that the sea-level cycles were symmetrical and that the maximum-flooding surfaces formed $10 \mathrm{kyr}$ after the sequence boundaries.

In order to best explain the observed features along the chosen time lines, an initial tectonic control has to be postulated, which determined the position of the reefs and ooid shoals at Hautes-Roches and Gorges de Court (Fig. 10). Periodically, there was also emersion in this area, as testified by charophytes at Hautes-Roches and tidal flats at Court. This topographic high was very close to the open-marine realm because stenohaline brachiopods and echinoderms are found together with charophytes. A barrier system of unknown nature must be assumed south of Pertuis and Savagnières, in order to produce the protected lagoonal facies there. Occasionally, ooid shoals developed close to these sites. At the time when sequence boundary (a) formed, climate must have been humid, and siliciclastics were shed onto the platform. Savagnières was less affected by this input, and a slight topographic high is assumed in that area. This high could be the result of differential subsidence but may have been enhanced by the accumulation of thick ooid shoals $300 \mathrm{kyr}$ before (Fig. 6). Siliciclastic input then diminished rapidly, partly due to a drier climate, partly to sealevel rise at the beginning of a 400-kyr eccentricity cycle. Biogenic carbonate production was high because the ecological conditions were favourable, and ooids formed because the water was warm and well saturated. Sediment accumulation kept pace with rising sea level. Sea-level falls related to the 20-kyr precession cycle were attenuated by the general rising trend and inflicted only minor channel formation at Vorbourg. Hautes-Roches was dominated by ooid shoals, with a sand wave forming in a tidal pass. The development of a tidal flat with microbial mats on top of the coral reef at Gorges de Court possibly implies a seasonally wet climate at sequence boundary (d) (Wright \& Burchette, 1996).

These reconstructions, albeit interpretative, clearly show that at any time the platform was structured and hosted several, juxtaposed depositional environments. Seafloor topography was created by differential subsidence but also by reefal constructions and accumulation of ooid shoals. The input of siliciclastics, triggered by falling sea level and by increased rainfall in the hinterland, slowed down carbonate production. It is therefore not a contradiction to postulate relatively deep lagoons at sequence boundary (a) and shallower environments at the time of maximum flooding (c) (Fig. 10). The source areas for the siliciclastics 
were most probably the Bohemian and/or Central massifs, which implies long transport distances (Fig. 5). Consequently, a time lag must be assumed between the increased erosion of the hinterland and the final deposition of the material in the study area.

At the scale of this study (sections spaced a few kilometres, time lines spaced a few ten-thousand years), facies mosaics are not random but linked to sea-level changes, tectonics, climate and ecology. On smaller scales, however, random processes defining the exact position and composition of each facies may become important (Rankey, 2002; Wright \& Burgess, 2005). In a road-cut close to Roderis (18 km ENE of Vorbourg), in the Steinebach Member, Samankassou et al. (2003) have described important facies changes occurring over a few metres only: a coral reef is laterally replaced by coral rubble then by ooids over a distance of $2.5 \mathrm{~m}$, another reef passes laterally into a tidal flat over $14 \mathrm{~m}$. Thus, reef growth determined the depositional environments in the immediate neighbourhood. Such relationships demonstrate that ancient facies mosaics were as complex as modern ones.

\section{Sedimentation rates}

When estimating sedimentation rates, it is paramount to specify the time interval over which they are calculated (Sadler, 1981; Schlager, 1999). When simply dividing the thickness of a stratigraphic column by the number of million years it represents, only average rates of sediment preservation are obtained. Original carbonate production rates certainly were much higher, but part of the sediment was exported, and time was consumed in hiatuses. Sediment compaction through time also has to be considered. To approximate the sediment production of ancient carbonate systems, the time interval over which the rates are calculated has to be as short as possible, in order to avoid inclusion of hiatuses. The time resolution obtained by cyclostratigraphy is $10 \mathrm{kyr}$ at best, if a maximum-flooding surface can be recognized within an elementary sequence shown to correspond to the $20-\mathrm{kyr}$ precession cycle (assuming that the sea-level cycle was symmetrical). On the other hand, it is improbable to find perfectly isochronous layers or surfaces in ancient shallow-water carbonates. Time-averaging is caused by reworking of older particles that are incorporated in younger sediment, by sediment being washed back and forth for hundreds of years before it finally accumulates and is preserved, and/ or by bioturbation that may vertically mix tens of centimetres of sediment. Hardgrounds or emersion surfaces that are interpreted as time lines on the cyclostratigraphical (10-kyr) scale may record hundreds of years of non-deposition, physical erosion and/or dissolution and cannot be considered isochronous if a higher time resolution is sought.

Different carbonate environments have different sediment production rates, which is clearly demonstrated for the Holocene (Enos, 1991; Bosence, 1995; Gischler, 2003). Therefore, a comparison between recent and ancient platforms is only reasonable if ancient sedimentation rates are calculated separately for each facies, and if non-deposition, reworking and erosion are also considered (Strasser \& Samankassou, 2003). In the protected lagoonal setting of Pertuis, elementary sequences 3 and 4 do not show any signs of reworking or erosion. If a decompaction factor of 2 is applied for these homogeneous wackestones (Strasser \& Samankassou, 2003), the original thicknesses amount to 245 and $220 \mathrm{~cm}$, respectively. They have been deposited over a period of $20 \mathrm{kyr}$ each, which results in average sedimentation rates of about $0.11-0.12 \mathrm{~mm} \mathrm{yr}^{-1}$. The maximum-flooding surfaces have not been placed in the middle of these sequences (Fig. 9): either the chosen bedding surfaces do not correspond to maximum flooding, or the sea-level cycle was asymmetric, or the sedimentation rates varied through the sequences. Tropical-subtropical Holocene lagoons have sedimentation rates ranging widely from 0.1 to $4 \mathrm{~mm}$ (Enos, 1991). The coral reef at Gorges de Court probably formed mostly during the transgressive phase of a 20-kyr sea-level cycle. The highstand is very thin and composed of a tidal flat (Fig. 9). The reef is $226 \mathrm{~cm}$ thick; compaction of this boundstone is negligible. Consequently, reef growth rate can be estimated at $0.23 \mathrm{mmyr}^{-1}$ on average. This is low when compared with Holocene reefs, which have vertical accretion rates of up to $14 \mathrm{~mm} \mathrm{yr}^{-1}$ (Enos, 1991). The low growth rate of the Oxfordian patch reefs is explained by the at times unfavourable ecological conditions (see above). The ooid shoal in the highstand of elementary sequence 2 (Fig. 9) is preserved with a thickness of $120 \mathrm{~cm}$. If decompacted, this would represent about $144 \mathrm{~cm}$ (assuming a decompaction factor for grainstones of 1.2; Strasser \& Samankassou, 2003). The time span is estimated at $10 \mathrm{kyr}$ (half a precession cycle), which results in a rate of $0.144 \mathrm{~mm} \mathrm{yr}^{-1}$. This number of course does not have any sedimentological meaning, 
knowing that there is an erosion surface at the top of the bed, that ooid shoals prograde and migrate laterally, and that much of the sediment may have been exported from the site of production. Ooid shoals today accumulate with rates of 0.5-2 $\mathrm{mm} \mathrm{yr}^{-1}$ (Schlager, 1981; Enos, 1991).

\section{CONCLUSIONS}

A study in the Oxfordian of the Swiss Jura has shown that ancient shallow-water carbonate systems are as complex as modern ones. In order to obtain a short time-frame within which the lateral and vertical facies distribution in ancient strata can be monitored, a cyclostratigraphic analysis is necessary. In the case of the interval studied, bio- and sequence-stratigraphic calibration as well as the hierarchical stacking pattern of depositional sequences allows a time resolution of 100 to $20 \mathrm{kyr}$ to be obtained, which corresponds to the orbital short eccentricity and precession cycles, respectively. Small-scale sequences related to the $100-k y r$ orbital cycles are generally well developed, while elementary (20-kyr) sequences often are difficult to identify because facies contrasts are weak, or because local factors create facies changes that are independent of an orbital control. Correlation of elementary sequences between sections therefore is not always possible.

On the 100-kyr as well as on the 20 -kyr scales, significant lateral facies heterogeneity is observed in the interval studied. While differential subsidence created a relief that pre-determined the positions of coral reefs, ooid shoals and protected lagoons, high-frequency sea-level changes in tune with the orbital insolation cycles gave the beat for the formation of depositional sequences. Lateral migration of sediment bodies may have been forced by sea-level fall but could also have happened under the influence of currents, independently of sea level. Climate fluctuated between humid and dry, which at least partly controlled the input of siliciclastics and nutrients from the hinterland. This terrigenous input had a negative impact on the coral patch-reefs, which suffered from eutrophication.

Although the distances between the sections studied are of several kilometres and the reconstructed time lines have a resolution of $10 \mathrm{kyr}$ at the most (from sequence boundary to maximum flooding of a 20-kyr precession cycle), it can be demonstrated that different depositional environments were juxtaposed and shifted position through time. Especially the sea-level falls related to the 100-kyr cyclicity appear to have punctuated the sedimentation history and forced the platform to reorganize itself. Thus, even if the general facies distribution was controlled by the tectonically induced platform morphology, the establishment of complex facies mosaics probably also had a random component.

High time resolution also allows for the estimation of sedimentation rates separately for each small-scale or elementary sequence and, if a maximum-flooding surface can be identified, separately for transgressive and highstand deposits. The sedimentation rates derived from this Oxfordian study are more or less comparable to the ones estimated for Holocene tropical-subtropical carbonate environments. Nevertheless, ancient reefal and lagoonal ecosystems must be interpreted with care because of preservational bias. Also, the ecological requirements and carbonate production rates may have differed considerably from today's reefs and lagoons, and high-frequency changes of water temperature, water chemistry and nutrient levels can only be guessed at. On the other hand, processes such as transport of ooid sands by tidal currents, mud accumulation in lagoons and on tidal flats, or burrowing by animals mixing the sediment certainly occurred in similar conditions as they happen today.

Late Jurassic climatic and sea-level changes had much lower amplitudes than those in the Quaternary, plate-tectonic configuration and oceanic circulation were fundamentally different, and there were many evolutionary steps between the Late Jurassic and today's fauna and flora, yet there are still many common features. As such, looking at modern shallow-water carbonate systems therefore remains a good means to improve one's understanding of ancient carbonate platforms, and there is no reason to abandon the concept of 'Comparative Sedimentology' put forward by Robert N. Ginsburg in the early 1970s.

\section{ACKNOWLEDGEMENTS}

The financial support of the Swiss National Science Foundation (Projects Nos. 20-67736.02 and 109214.05) is gratefully acknowledged. We thank Elias Samankassou for his constructive remarks on a first version of this paper, and David Osleger and Christophe Dupraz for their careful reviews. We also thank Peter Swart and Judith McKenzie for the editing. 


\section{REFERENCES}

Abbink, O., Targarona, J., Brinkhuis, $\mathrm{H}$. and Visscher, $\mathrm{H}$ (2001) Late Jurassic to earliest Cretaceous palaeoclimatic evolution of the southern North Sea. Global Planet. Change, 30, 231-256.

Allenbach, R.P. (2001) Synsedimentary tectonics in an epicontinental sea: a new interpretation of the Oxfordian basins of northern Switzerland. Eclogae Geol. Helv., 94, 265-287.

Berger, A., Loutre, M.F. and Dehant, V. (1989) Astronomical frequencies for pre-Quaternary palaeoclimate studies. Terra Nova, 1, 474-479.

Bolliger, W. and Burri, P. (1970) Sedimentologie von SchelfCarbonaten und Beckenablagerungen im Oxfordien des zentralen Schweizer Jura. Beitr. Geol. Karte Schweiz, 140, 96.

Bosence, D.W.J. (1995) Anatomy of a recent biodetrital mud-mound, Florida Bay, USA. Int. Assoc. Sedimentol. Spec. Publ., 23, 475-493.

Burchette, T.P. and Wright, V.P. (1992) Carbonate ramp depositional systems. Sed. Geol., 79, 3-57.

Church, J.A. and Gregory, J.M. (2001) Changes in sea level. In: Climate Change 2001, the Scientific Basis. Intergovernmental Panel on Climate Change, Cambridge University Press, Cambridge, pp. 639-693.

De Boer, P.L. and Smith, D.G. (1994) Orbital forcing and cyclic sequences. In: Orbital Forcing and Cyclic Sequences (Eds P.L. De Boer and D.G. Smith). Int. Assoc. Sedimentol. Spec. Publ., 19, 1-14.

Dercourt, J., Ricou, L.E. and Vrielynck, B. (Eds) (1993) Atlas: Tethys Palaeoenvironmental Maps. GauthierVillars, Paris, $307 \mathrm{pp}$.

Dupraz, C. (1999) Paléontologie, paléoecologie et évolution des faciès récifaux de l'Oxfordien Moyen-Supérieur (Jura suisse et français). GeoFocus, 2, 1-241.

Dupraz, C. and Strasser, A. (2002) Nutritional modes in coral-microbialite reefs (Jurassic, Oxfordian, Switzerland): evolution of trophic structure as a response to environmental change. Palaios, 17, 449-471.

Enos, P. (1991) Sedimentary parameters for computer modeling. In: Sedimentary Modeling, Computer Simulations and Methods for Improved Parameter Definition (Eds E.K. Franseen, W.L. Watney, C.G.St.C. Kendall and W. Ross). Kansas Geol. Survey Bull., 233, 63-99.

Eyles, N. (1993) Earth's glacial record and its tectonic setting. Earth-Sci. Rev., 35, 1-248.

Fairbridge, R.W. (1976) Convergence of evidence on climatic change and ice ages. Ann. N.Y. Acad. Sci., 91, 542-579.

Flügel, E. (2004) Microfacies of Carbonate Rocks. Springer, Berlin, 976 pp.

Frakes, L.A., Francis, J.E. and Syktus, J.I. (1992) Climate Modes of the Phanerozoic. Cambridge University Press, Cambridge, $274 \mathrm{pp}$.

Ginsburg, R.N. (1971) Landward movement of carbonate mud: new model for regressive cycles in carbonates (abstract). Bull. Am. Ass. Petrol. Geol., 55, 340.

Gischler, E. (2003) Holocene lagoonal development in the isolated carbonate platforms off Belize. Sed. Geol., 159, 113-132.

Gischler, E. and Lomando, A.J. (1999) Recent sedimentary facies of isolated carbonate platforms, Belize-Yucatan system, Central America. J. Sed. Res., 69, 747-763.
Goldhammer, R.K., Dunn, P.A. and Hardie, L.A. (1990) Depositional cycles, composite sea-level changes, cycle stacking patterns, and the hierarchy of stratigraphic forcing: examples from Alpine Triassic platform carbonates. Bull. Geol. Soc. Am., 102, 535-562.

Gornitz, V., Lebedeff, S. and Hansen, J. (1982) Global sea-level trend in the past century. Science, 215, 1611-1614.

Gradstein, F.M., Agterberg, F.P., Ogg, J.G., Hardenbol, J., van Veen, P., Thierry, J. and Huang, Z. (1995) A Triassic, Jurassic and Cretaceous time scale. In: Geochronology, Time Scales and Global Stratigraphic Correlation (Eds W.A. Berggren, D.V. Kent, M.P. Aubry and J. Hardenbol). Soc. Sed. Geol. Spec. Publ., 54, 95-126.

Gygi, R.A. (1986) Eustatic sea level changes of the Oxfordian (Late Jurassic) and their effect documented in sediments and fossil assemblages of an epicontinental sea. Eclogae Geol. Helv., 79, 455-491.

Gygi, R.A. (1995) Datierung von Seichtwassersedimenten des Späten Jura in der Nordwestschweiz mit Ammoniten. Eclogae Geol. Helv., 88, 1-58.

Gygi, R.A. and Persoz, F. (1986) Mineralostratigraphy, litho- and biostratigraphy combined in correlation of the Oxfordian (Late Jurassic) formations of the Swiss Jura range. Eclogae Geol. Helv., 79, 385-454.

Gygi, R.A., Coe, A.L. and Vail, P.R. (1998) Sequence stratigraphy of the Oxfordian and Kimmeridgian stages (Late Jurassic) in northern Switzerland. In: Mesozoic and Cenozoic Sequence Stratigraphy of European Basins (Eds P.-C. De Graciansky, J. Hardenbol, T. Jacquin and P.R. Vail). Soc. Sed. Geol. Spec. Publ., 60, 527-544.

Hardenbol, J., Thierry, J., Farley, M.B., Jacquin, T., De Graciansky, P.-C. and Vail, P.R. (1998) Jurassic sequence chronostratigraphy (chart). In: Mesozoic and Cenozoic Sequence Stratigraphy of European Basins (Eds P.-C. De Graciansky, J. Hardenbol, T. Jacquin and P.R. Vail). Soc. Sed. Geol. Spec. Publ., 60.

Hug, W. (2003) Sequenzielle Faziesentwicklung der Karbonatplattform des Schweizer Jura im Späten Oxford und frühesten Kimmeridge. GeoFocus, 7, 156 pp.

Jacobs, D.K. and Sahagian, D.L. (1993) Climate-induced fluctuations in sea level during non-glacial times. Nature, 361, 710-712.

Jones, B. and Desrochers, A. (1992) Shallow platform carbonates. In: Facies Models - Response to Sea Level Change (Eds R.G Walker and N.P. James). Geol. Ass. Canada, 277-301.

Kendall, C.G.St.C. and Schlager, W. (1981) Carbonates and relative changes in sea level. Marine Geol., 44, 181-212.

Matthews, M.D. and Perlmutter, M.A. (1994) Global cyclostratigraphy: an application to the Eocene Green River basin. In: Orbital Forcing and Cyclic Sequences (Eds P.L. De Boer and D.G. Smith). Int. Assoc. Sedimentol. Spec. Publ., 19, 459-481.

Mutti, M. and Hallock, P. (2003) Carbonate systems along nutrient and temperature gradients: some sedimentological and geochemical constraints. Int. J. Earth Sci., 92, 465-475.

Oschmann, W. (1990) Environmental cycles in the late Jurassic northwest European epeiric basin: interaction with atmospheric and hydrospheric circulations. Sed. Geol., 69, 313-332. 
Pittet, B. (1996) Contrôles climatiques, eustatiques et tectoniques sur des systèmes mixtes carbonates-siliciclastiques de plate-forme: exemples de l'Oxfordien (Jura suisse, Normandie, Espagne). Unpublished doctoral dissertation, University of Fribourg, $258 \mathrm{pp}$.

Pittet, B. and Strasser, A. (1998) Long-distance correlations by sequence stratigraphy and cyclostratigraphy: examples and implications (Oxfordian from the Swiss Jura, Spain, and Normandy). Geol. Rundschau, 86, 852-874.

Plunkett, J.M. (1997) Early diagenesis of shallow platform carbonates in the Oxfordian of the Swiss Jura Mountains. Unpublished doctoral dissertation, University of Fribourg, 167 pp.

Pomar, L. (2001) Types of carbonate platforms: a genetic approach. Basin Res., 13, 313-334.

Pratt, B.R. and James, N.P. (1986) The St George Group (Lower Ordovician) of western Newfoundland: tidal flat island model for carbonate sedimentation in shallow epeiric seas. Sedimentology, 33, 313-343.

Rankey, E.C. (2002) Spatial patterns of sediment accumulation on a Holocene carbonate tidal flat, northwest Andros Island, Bahamas. J. Sed. Res., 72, 591-601.

Read, J.F. (1985) Carbonate platform facies models. Am. Assoc. Petrol. Geol. Bull., 69, 1-21.

Riegl, B. and Piller, W.E. (1999) Coral frameworks revisited - reefs and coral carpets in the northern Red Sea. Coral Reefs, 18, 241-253.

Sadler, P.M. (1981) Sediment accumulation rates and the completeness of stratigraphic sections. J. Geol., 89, 569-584

Samankassou, E., Strasser, A., Di Gioia, E., Rauber, G. and Dupraz, C. (2003) High-resolution record of lateral facies variations on a shallow carbonate platform (Upper Oxfordian, Swiss Jura Mountains). Eclogae Geol. Helv., 96, 425-440.

Schlager, W. (1981) The paradox of drowned reefs and carbonate platforms. Geol. Soc. Am. Bull., 92, 197-211.

Schlager, W. (1999) Scaling of sedimentation rates and drowning of reefs and carbonate platforms. Geology, 27, 183-186.

Schlager, W. (2003) Benthic carbonate factories in the Phanerozoic. Int. J. Earth Sciences, 92, 445-464.

Schulz, M. and Schäfer-Neth, C. (1998) Translating Milankovitch climate forcing into eustatic fluctuations via thermal deep water expansion: a conceptual link. Terra Nova, 9, 228-231.

Schwarzacher, W. (1993) Cyclostratigraphy and the Milankovitch Theory. Dev. Sedimentol., 52, 225

Sellwood, B.W. and Valdez, P.J. (1997) Geological evaluation of climate General Circulation Models and model implications for Mesozoic cloud cover. Terra Nova, 9, 75-78.

Strasser, A. (1991) Lagoonal-peritidal sequences in carbonate environments: autocyclic and allocyclic processes. In: Cycles and Events in Stratigraphy (Eds G. Einsele, W. Ricken and A. Seilacher). Springer, Berlin, pp. 709-721.

Strasser, A. and Hillgärtner, H. (1998) High-frequency sea-level fluctuations recorded on a shallow carbonate platform (Berriasian and Lower Valanginian of Mount Salève, French Jura). Eclogae Geol. Helv., 91, 375-390.

Strasser, A. and Samankassou, E. (2003) Carbonate sedimentation rates today and in the past: Holocene of Florida Bay, Bahamas, and Bermuda vs. Upper Jurassic and Lower Cretaceous of the Jura Mountains (Switzerland and France). Geol. Croatica, 56, 1-18.

Strasser, A., Hillgärtner, H., Hug, W. and Pittet, B. (2000) Third-order depositional sequences reflecting Milankovitch cyclicity. Terra Nova, 12, 303-311.

Strasser, A., Hillgärtner, H. and Pasquier, J.-B. (2004) Cyclostratigraphic timing of sedimentary processes: an example from the Berriasian of the Swiss and French Jura Mountains. In: Cyclostratigraphy: Approaches and Case Histories (Eds B. D’Argenio, A.G. Fischer, I. Premoli Silva, H. Weissert and V. Ferreri). Soc. Sed. Geol. Spec. Publ., 81, 135-151.

Strasser, A., Pittet, B., Hillgärtner, H. and Pasquier, J.-B. (1999) Depositional sequences in shallow carbonate-dominated sedimentary systems: concepts for a high-resolution analysis. Sed. Geol., 128, 201-221.

Vail, P.R., Audemard, F., Bowman, S.A., Eisner, P.N. and Perez-Cruz, C. (1991) The stratigraphic signatures of tectonics, eustasy and sedimentology - an overview. In: Cycles and Events in Stratigraphy (Eds G. Einsele, W. Ricken and A. Seilacher). Springer, Berlin, pp. 617-659.

Valdes, P.J., Sellwood, B.W. and Price, G.D. (1995) Modelling Late Jurassic Milankovitch climate variations. In: Orbital Forcing Timescales and Cyclostratigraphy (Eds M.R. House and A.S. Gale). Geol. Soc. Spec. Publ., 85, 115-132.

Védrine, S. (2007) High-frequency palaeoenvironmental changes in mixed carbonate-siliciclastic sedimentary systems (Late Oxfordian, Switzerland, France, and southern Germany). GeoFocus, 19, 216 pp.

Wildi, W., Funk, H., Loup, B., Amato, E. and Huggenberger, P. (1989) Mesozoic subsidence history of the European marginal shelves of the Alpine Tethys (Helvetic realm, Swiss Plateau and Jura). Eclogae Geol. Helv., 82, 817-840.

Wilson, J.L. (1975) Carbonate Facies in Geologic History. Springer, Berlin, $471 \mathrm{pp}$.

Wright, V.P. and Burchette, T.P. (1996): Shallow-water carbonate environments. In: Sedimentary Environments Processes, Facies and Stratigraphy (Ed. H.G. Reading), 3rd ed. Blackwell, London, pp. 325-394.

Wright, V.P. and Burgess, P.M. (2005) The carbonate factory continuum, facies mosaics and microfacies: an appraisal of some of the key concepts underpinning carbonate sedimentology. Facies, 51, 19-25.

Ziegler, P.A. (1956) Zur Stratigraphie des Séquanien im zentralen Schweizer Jura. Beitr. Geol. Karte Schweiz, 102, 37-101

Ziegler, P.A. (1988) Late Jurassic - Early Cretaceous Central Atlantic sea-floor spreading, closure of Neo-Tethys, and opening of Canada Basin. In: Evolution of the ArcticNorth Atlantic and the Western Tethys (Ed. P.A. Ziegler). Am. Assoc. Petrol. Geol. Mem., 43, 63-82. 